Kiryoku, Volume 3 No 32019

e-ISSN: 2581-0960 p-ISSN: 2599-0497

Tersedia online di http://ejournal.undip.ac.id/index.php/kiryoku

\title{
BENTUK YOU TO SURU DALAM KALIMAT BAHASA JEPANG
}

\author{
E.I.H.A. Nindia Rini \\ Universitas Diponegoro \\ eliz_ikahesti@yahoo.co.id
}

\begin{abstract}
Abstrak
Bentuk -you to suru memiliki dua fungsi, yaitu sebagai penanda modalitas intensional dan penanda aspek inkoatif. Penelitian ini bertujuan mendeskripsikan struktur dan makna bentukyou to suru agar dapat menggunakannyai dalam situasi yang tepat. Metode yang digunakan pada penelitian ini adalah agih dengan teknik bagi unsur langsung. Sebagai hasil penelitian ditemukan bahwa bentuk -you to suru sebagai penanda modalitas niatan menyatakan usaha dalam melakukan sesuatu dan sebagai penanda aspek inkoatif menyatakan menyatakan dimulainya suatu aktivitas. Sebagai penanda modalitas niatan, bentuk -you to suru melekat pada verba volisional; sedangkan sebagai penanda aspek inkoatif bentuk -you to suru melekat pada verba baik volisional dan non volisional.
\end{abstract}

Kata kunci :bentuk -you to suru, modalitas niatan, aspek inkoatif

\begin{abstract}
(Title: ryou to suru in Japanese Language) -You to suru form has two functions, i.e. as a marker of interpersonal modality and a marker of incoative aspects. This study aims to describe the structure and meaning of -you to suru form in order to use it in the right situation. The method used in this study is agih method, and bagi unsur langsung techniques. As a result of the research, it was found that -you to suru form as a marker of intention modality stated effort in doing something; and as a marker of the incoative aspect stated the start of an activity. As a marker of intention modality, the form of -you to suru is attached to volitional verbs; while as a marker of the incoative aspect, -you to suru form is attached to both volitional and non volitional verbs.
\end{abstract}

Keywords : -you to suru, inter personal modality, inchoative aspect marker

\section{PENDAHULUAN}

Modalitas merupakan kategori gramatikal yang digunakan pembicara dalam menyatakan sikap terhadap situasi, keadaan, atau peristiwa kepada lawan bicaranya, seperti menginformasikan, menyuruh, melarang, meminta, dan sebagainya dalam kegiatan berkomunikasi. Modalitas dalam bahasa Jepang terbagi atas inter propositional modality (taijiteki modariti 対事的モダリテイ) dan inter personal modality (taijinteki modarity 対
人的モダリティー). Salah satu dari bahasan inter personal modality (taijinteki modarity 対人的モダリティー) adalah modalitas intensional yaitu modalitas yang menyatakan sikap pembicara terhadap lawan bicaranya, dalam hal ini terkait dengan niatan (意志 $i s h i$ ).

Sedangkan spek (アスペクト・相 asupekuto atau sou) merupakan kategori gramatikal yang mempermasalahkan pada tahap (局面 kyokumen) manakah peristiwa itu berada (Iori, 2001:152). Tahapan yang 
dimaksud disini misalnya, tahap awal (開 始 kaishi), tahap keberlangsungan (継続 keizoku), tahap akhir (終了shuuryou), dan lain-lain. Salah satu bahasan aspek adalah aspek inkoatif yaitu aspek yang memberikan penekanan pada tahap awal atau segi permulaan keberlangsungan sebuah situasi (Tadjuddin, 2005:39).

Bentuk -you to suru dikenal sebagai penanda modalitas intensional dan aspek inkoatif.

Penelitian terdahulu yang terkait dengan penelitian ini adalah penelitian Nindia Rini mengenai verba kompon -hajimeru, -dasu, maupun -kakeru sebagai penanda aspek inkoatif. Penelitian ini bertujuan mendeskripsikan struktur dan makna ketiga verba kompon tersebut. Metode yang digunakan pada penelitian ini adalah metode deskriptif. Sebagai hasil penelitian ditemukan bahwa verba kompon -hajimeru digunakan untuk menyatakan mulainya aktivitas atau peristiwa pada umumnya; verba kompon -dasu digunakan untuk menyatakan dimulainya aktivitas yang terjadi tiba-tiba; sedangkan verba kompon -kakeru menyatakan sesaat akan dimulainya dan sesaat setelah dimulainya aktivitas. Perbedaan penelitian ini dengan penelitian terdahulu adalah bahwa penelitian ini melengkapi bahasan mengenai penanda aspek inkoatif bahasa Jepang dengan mengkaji bentuk -you to suru yang salah satu fungsinya adalah sebagai penanda aspek inkoatif. Selain itu penelitian ini juga akan dilengkapi dengan pemaparan fungsi bentuk -you to suru sebagai penanda modalitas.

Penelitian lainnya terkait penelitian ini, adalah penelitian Pertiwi (2018) mengenai modalitas tsumori dalam kalimat bahasa Jepang. Sebagai hasil penelitian ini disimpulkan bahwa modalitas tsumori dapat melekat pada verba, adjektiva, maupun nomina. Kemudian dilihat dari segi makna, modalitas tsumori menunjukkan keyakinan atau keinginan akan suatu hal / tindakan yang dilakukan. Niat yang disampaikan menggunakan bentuk tsumori menunjukkan niat yang sudah dipikirkan dan diputuskan sebelumnya sehingga bukan merupakan keputusan yang spontan. Penelitian penulis mengambil bentuk -you to suru sebagai lanjutan penelitian terdahulu milik Pertiwi yang sama-sama mengkaji tentang modalitas intensional. Penelitian penulis diharapkan dapat melengkapi penelitian mengenai modalitas yang menyatakan niatan.

Tujuan penelitian ini adalah untuk memaparkan struktur dan makna bentuk -you to suru.

\section{METODE}

Metode yang yang digunakan pada penelitian ini adalah metode agih dengan teknik bagi unsur langsung. Metode agih adalah metode yang alat penentunya merupakan bagian dari bahasa itu sendiri (Sudaryanto, 1993:15). Sedangkan teknik bagi unsur langsung diterapkan dengan membagi unsur-unsur sesuai dengan fungsinya dalam kalimat. Dalam hal ini akan dijelaskan mengenai jenis dan makna predikat yang dilekati bentuk -you to suru.

Kemudian hasil penelaahan lalu dipaparkan dengan metode deskriptif untuk membuat gambaran, lukisan secara sistematis, faktual dan akurat mengenai data, sifat-sifat serta hubungan fenomenafenomena yang diteliti (Djajasudarma, $2010: 9)$.

\section{HASIL DAN PEMBAHASAN Bentuk - you to suru}

Bentuk -you to suru berkonstruksi dengan verba volisional (ishi doushi) seperti taberu 'makan', matsu 'menunggu', hairu 'masuk', kaeru 'pulang', neru 'tidur', omoidasu 'ingat', dan lain-lain; maupun non volisional (muishi doushi) seperti afureru 'meluap', kureru 'menjadi gelap', nakunaru 'menjadi hilang / habis', kieru 'mati', shizumu 'terbenam', noboru 'naik'; 
Kiryoku, Volume 3 No 32019

e-ISSN: 2581-0960 p-ISSN: 2599-0497

Tersedia online di http://ejournal.undip.ac.id/index.php/kiryoku

dengan subjek berupa makhluk hidup maupun benda mati.

Ketika melekat pada verba volisional, bentuk -you to suru menyatakan dua makna, pertama sebagai penanda modalitas intensional yang menyatakan niatan, -you to suru menyatakan usaha atau upaya dalam merealisasikan suatu aktivitas atau perkara; dan kedua sebagai penanda aspek inkoatif yang menyatakan tahap awal dari aktivitas atau peristiwa, -you to suru menyatakan tahap sesaat sebelum suatu aktivitas atau peristiwa terjadi.

Sedangkan, pelekatan bentuk -you to suru pada verba non volisional ada yang menyatakan fenomena alam yang terjadi tanpa niat (pelaku).

Berikut ini adalah penggunaan bentuk -you to suru dalam kalimat.

\section{A. Makna Upaya Merealisasikan Sesuatu}

(1) 節約のために少しでも電気代を減 らそうとしている。

(Ichikawa, 2015:142)

Setsuyaku no tame ni sukoshi demo denkidai o herasou to shite iru. 'Untuk menghemat, (saya) berusaha mengurangi biaya listrik barang sedikit.'

Pada kalimat (1) bentuk -you to shite iru berkonstruksi dengan verba volisional herasu 'mengurangi'. Bentuk -you to shite iru pada kalimat tersebut menyatakan upaya subjek untuk menghemat dengan mengurangi pemakaian listrik.

（2）おばあさんは道を渡ろうとしてい ますが、車が多くて渡れません。

(Tomomatsu, 2006:115)

Obaasan wa michi o watarou to shite imasu ga, kuruma ga ookute wataremasen.

'Nenek berusaha menyeberang jalan, tetapi karena banyak mobil, (ia) tidak bisa menyeberang.'
Pada kalimat (2) bentuk -you to shite iru sebagai penanda modalitas intensional berkonstruksi dengan verba volisional wataru 'menyeberang'. Bentuk -you to shite iru pada kalimat tersebut menyatakan upaya obaasan 'nenek' sebagai subjek untuk menyeberangi jalan yang ramai, namun usahanya tidak terealisasi karena jalanan yang ramai.

（3）今朝 6 時に起きようとしましたが、 起きられませんでした。

(Tomomatsu, 2006:115)

Kesa 6 ji ni okiyou to shimashita ga, okiraremasendeshita.

'Tadi pagi (saya) berusaha untuk bangun pukul 6, tetapi tidak terbangun.'

Pada kalimat (3) bentuk -you to suru berkonstruksi dengan verba volisional okiru 'bangun'. Bentuk -you to suru pada kalimat tersebut menyatakan niat subjek yang dalam kalimat tersebut dilesapkan, untuk bangun pada pukul 6 , namun tidak tercapai.

（4）彼女は 25 歳になる前に何とか結婚 しようとしている。(Sunagawa, 1999:614)

Kanojo wa 25 sai ni naru mae ni nantoka kekkon shiyou to shite iru.

'Dia sedapat mungkin berusaha menikah sebelum usia 25 tahun.'

Pada kalimat (4) bentuk -you to shite iru berkonstruksi dengan verba volisional kekkon suru 'menikah'. Bentuk -you to shite iru pada kalimat tersebut menyatakan upaya subjek kanojo 'dia' untuk merealisasi menikah sebelum usianya genap 25 tahun.

（5）いくら思い出そうとしても名前が 思い出せない。(Sunagawa, 1999:614) 
Ikura omoidasou to shitemo namae ga omoidasenai.

'Bagaimanapun usaha (saya) untuk mengingat, namanya tidak bisa (saya) ingat.'

Pada kalimat (5) bentuk -you to suru berkonstruksi dengan verba volisional omoidasu 'mengingat'. Bentuk -you to suru pada kalimat tersebut menyatakan upaya subjek untuk mengingat nama seseorang, namun tidak bisa.

（6）棚の上の花瓶をとろうとして、足 が踏みはずしてしまった。 (Sunagawa, 1999:614)

Tana no ue no kabin o torou to shite, ashi ga fumihazushite shimatta.

'Saat berusaha mengambil vas bunga di lemari, kaki saya salah melangkah.'

Pada kalimat (6) bentuk -you to suru berkonstruksi dengan verba volisional toru 'mengambil'. Bentuk -you to suru pada kalimat tersebut menyatakan upaya subjek untuk mengambil vas bunga yang berada di atas lemari, namun kakinya salah berpijak.

（7）田中はたき火を水で消そうとした。 (Nitta, 2012:61)

Tanaka san wa takibi o mizu de kesou to shita.

'Tanaka bermaksud mematikan api unggun.'

Pada kalimat (7) bentuk -you to suru berkonstruksi dengan verba volisional kesu 'mematikan'. Bentuk -you to suru pada kalimat tersebut menyatakan upaya Tanaka sebagai subjek untuk mematikan api unggun.
（8）寝ようとすればするほど、目が讶 えてきてしまった。(Sunagawa, 1999:614)

Neyou to sureba suru hodo, me ga saete kite shimatta.

'Semakin berusaha untuk tidur, mata (saya) semakin jernih.'

Pada kalimat (8) bentuk -you to suru berkonstruksi dengan verba volisional neru 'tidur'. Bentuk -you to suru pada kalimat tersebut menyatakan bahwa semakin subjek berupaya untuk tidur, matanya malah semakin segar.

Dari paparan di atas diketahui bahwa sebagai penanda modalitas intensional, bentuk -you to suru melekat pada verba volisional dengan subjek makhluk hidup (manusia).

\section{B. Makna Sesaat Sebelum Aktivitas atau Peristiwa}

（9）出かけようとしたとき、携帯が鳴 った。(Ichikawa, 2015:142)

Dekakeyou to shita toki, keitai ga natta.

'Ketika akan berangkat, ponsel (saya) berdering.'

Pada kalimat (9) bentuk -you to suru berkonstruksi dengan verba volisional dekakeru 'berangkat'. Bentuk -you to suru dalam kala lampau you to shita pada kalimat tersebut menunjukkan tahap awal aktivitas berangkat; sehingga secara keseluruhan kalimat (9) di atas menggambarkan bahwa ketika subjek akan berangkat, ponselnya berdering.

(10)どうもおそくなりました。会社を 出ようとしたとき、社長に呼ばれ ました。(Tomomatsu, 2006:115) 
Kiryoku, Volume 3 No 32019

e-ISSN: 2581-0960 p-ISSN: 2599-0497

Tersedia online di http://ejournal.undip.ac.id/index.php/kiryoku

Doumo osoku narimashita. Kaisha o deyou to shita toki, shachou ni yobaremashita.

'Maaf terlambat. Saat akan keluar

dari kantor (perusahaan), (saya) dipanggil presiden direktur.

Pada kalimat (10) bentuk -you to suru berkonstruksi dengan verba volisional deru 'keluar'. Bentuk -you to suru dalam bentuk lampau -you to shita pada kalimat tersebut menunjukkan tahap awal aktivitas keluar perusahaan; sehingga secara keseluruhan kalimat (10) di atas menyatakan bahwa ketika subjek yang pada kalimat tersebut dilesapkan akan berangkat, dia dipanggil oleh presiden direktur.

(11)お風呂に入ろうとしたとき、電話 のベルが鳴つた。(Tomomatsu, 2006:115)

Ofurou ni hairou to shita toki, denwa no beru ga natta.

'Ketika akan masuk ofurou, telepon berdering.'

(12)お風呂に入ろうとしていたところ に、電話がかかっていた。 (Sunagawa, 1999:614)

Ofurou ni hairou to shite ita tokoro ni, denwa ga kakatteita.

'Ketika akan masuk ofurou, telepon berdering.'

Menurut Ichikawa (2015:142), bentuk -you to suru tidak banyak ditemui hanya dalam bentuk -you to suru saja di akhir kalimat, tetapi umumnya dilekati dengan konjungsi toki, tokoro, noni, ga, keredo, dan lain-lain.

Pada kalimat (11) dan (12) bentuk -you to suru berkonstruksi dengan verba volisional hairu 'masuk'. Bentuk -you to shita pada kalimat (11) dan -you to shite ita pada kalimat (12) tersebut menunjukkan tahap awal aktivitas masuk ofurou. Kedua kalimat tersebut terdiri dari dua klausa yang dihubungkan dengan konjungsi toki pada kalimat (11) dan tokoroni pada kalimat (12). Secara keseluruhan kalimat tersebut menyatakan ketika akan masuk ofurou, telepon milik subjek berdering.

\section{(13)今まさに夕日が沈もうとしている。 (Ichikawa, 2015:142) \\ Ima masani yuuhi ga shizumou to shite iru. \\ 'Tepat saat ini matahari sore akan terbenam.'}

Bentuk -you to shite iru pada kalimat (13) berkonstruksi dengan verba non volisional shizumu 'terbenam'. Bentuk -you to shite iru pada kalimat tersebut menunjukkan tahap mulainya peristiwa matahari terbenam (hampir terbenam).

(14)大雨で川の水が溢れようとしてい る。(Ichikawa, 2015:142)

Ooame de kawa no mizu ga afureyou to shite iru.

'Akibat hujan deras, air sungai hampir meluap.'

Pada kalimat (14) Bentuk -you to shite iru berkonstruksi dengan verba non volisional afureru 'meluap'. Bentuk -you to shite iru pada kalimat tersebut menunjukkan tahap mulainya peristiwa meluapnya air sungai (hampir meluap).

(15) 時計が正午を知らせようとしてい る。(Sunagawa, 1999:614)

Tokei ga shougo o shiraseyou to shite iru.

'Jam hampir menunjukkan waktu tengah hari.'

Bentuk -you to shite iru pada kalimat (15) berkonstruksi dengan verba volisional shiraseru 'memberitahukan'. Bentuk -you to shite iru pada kalimat tersebut menunjukkan tahap awal jam atau waktu 
menunjukkan tengah hari. Pada kalimat ini tokei sebagai subjek meskipun benda mati tetapi dengan predikat volisional shiraseru, diperlakukan seperti manusia yang dapat menunjukkan waktu.

\section{(16)長かった夏休みもじきに終わろう としている。(Sunagawa, 1999:614)}

Nagakatta natsu yasumi mo jiki ni owarou to shite iru.

'Musim panas yang panjang pun sebentar lagi akan berakhir.'

Bentuk -you to shite iru pada kalimat (16) berkonstruksi dengan verba non volisional owaru 'selesai. Bentuk -you to shite iru pada kalimat tersebut menunjukkan tahap awal berakhirnya liburan musim panas yang panjang (hampir berakhirnya).

(17) 上り坂にさしかかろうとするとこ ろで車がエンストを起こしてしま った。(Sunagawa, 1999:614)

Noborizaka ni sashikakarou to suru tokoro de kuruma ga ensuto o okoshite shimatta.

'Pada posisi hampir sampai tanjakan, timbul masalah pada mesin.'

Bentuk -you to suru pada kalimat (17) berkonstruksi dengan verba non volisional sashikakaru 'baru sampai'. Bentuk -you to suru pada kalimat tersebut menunjukkan tahap ketika mobil hampir sampai tanjakan, mobil mengalami masalah pada mesin.

\section{(18)この劇もまもなくクライマックス を迎えようとしている。(Nitta, 2012:61)}

Kono geki mo mamonaku kuraimakkusu o mukaeyou to shite iru. 'Drama ini pun sesaat lagi hampir mencapai klimaksnya.'
Bentuk -you to shite iru pada kalimat (18) berkonstruksi dengan verba volisional mukaeru 'bertemu'. Bentuk -you to shite iru pada kalimat tersebut menunjukkan bahwa drama yang tengah ditonton sesaat lagi mencapai klimaks (hampir mencapai puncak).

(19)この椅子は今にも壊れようとして いる。(Nitta, 2012:61)

Kono isu wa ima ni mo kowareyou to shite iru.

'Kursi ini dalam sekejap akan rusak.'

Bentuk -you to shite iru pada kalimat (19) berkonstruksi dengan verba non volisional kowareru 'rusak'. Bentuk -you to shite iru pada kalimat tersebut menunjukkan keadaan hampir rusaknya kursi ini.

Berikut ini adalah contoh penggunaan bentuk -you to suru dalam percakapan.

(20)A: どうしたの。包帯なんかして。 Doushita no. Houtai nanka shite. 'Kenapa (kamu)? Kok diperban?

B: 足を捻挫してしまったんです。 Ashi o nenza shite shimattandesu. 'Kaki (saya) keseleo.'

A: どこで?

Dokode?

'Di mana?'

B: 階段から降りようとしたとき、 踏み外してしまって。

Kaidan kara oriyou to shita toki, fumihazushite shimatte.

'Waktu akan turun tangga, (saya) melewatkan satu step anak tangga.'

A: .......まあ、大変 maa, taihen. '......waah, berat ya.' 
(21)A: どうしたの。 Doushita no?

'Kenapa?'

B: 階段から落ちて。

Kaidan kara ochite.

'Jatuh dari tangga.'

$$
\begin{gathered}
\text { A: また? } \\
\text { Mata? } \\
\text { 'Lagi?' }
\end{gathered}
$$

B: そうなんだ。階段から降りよう とするとき、いつも踏み外して しまうんだ。

Sounanda. Kaidan kara oriyou to suru toki, itsumo fumihazushite shimaundesu.

'Ya, betul. Ketika akan turun tangga, (saya) selalu melewatkan satu step anak tangga.'

\section{A：しょうがないわね。 Shouganai wa ne. \\ 'Apa boleh buat ya.'}

Pada kalimat (20) bentuk -you to shita yang melekat pada verba volisional oriru 'turun' menyatakan peristiwa lampau, sementara itu bentuk -you to suru pada kalimat (21) menyatakan sebuah kebiasaan yang ditandai oleh bentuk non lampau -you to suru. Kedua kalimat tersebut menyatakan tahap ketika akan turun tangga, subjek melewatkan satu anak tangga dan jatuh.

Sebagai penanda aspek inkoatif ini, bentuk -you to suru menunjukkan sesaat sebelum (直前 - 寸前 chokuzen / senzen) aktivitas atau perubahan dimulai atau selesai. Bentuk ini tipikal digunakan pada verba non volisional yang tidak berkaitan dengan niatan manusia, tetapi misalnya terlihat pada contoh nomor (9), (10), (11), (12) dimana terdapat konjungsi toki dan tokoroni, verba volisional juga dapat digunakan. Penggunaan verba non volisional pada bentuk -you to suru ini kebanyakan digunakan pada ungkapan sastra atau puitis (Sunagawa, 1999:614). Dan subjek pada makna ini bisa berupa makhluk hidup maupun benda mati.

\section{Simpulan}

Berdasarkan penjelasan di atas dapat ditarik simpulan sebagai berikut.

1. Bentuk -you to suru memiliki dua fungsi yaitu sebagai penanda modalitas intensional dan penanda aspek inkoatif.

2. Bentuk -you to suru sebagai penanda modalitas intensional berkonstruksi dengan verba volisional dengan subjek makhluk hidup. Sedangkan sebagai penanda aspek inkoatif, bentuk -you to suru melekat baik pada verba volisional maupun non volisional dengan subjek makhluk hidup dan benda mati.

3. Sebai penanda modalitas intensional, bentuk -you to suru menyatakan upaya atau usaha dalam merealisasikan sesuatu; sedangkan sebagai penanda aspek inkoatif bentuk -you to suru menyatakan makna sesaat sebelum.

\section{Daftar Pustaka}

Djajasudarma, Fatimah. 2010. Metode Linguistik : Ancangan Metode Penelitian dan Kajian. Bandung : Refika Aditama.

Ichikawa, Yasuko. 2015. Chuukyuu Nihongo Bunpou to Oshiekata no Pointo. Tokyo : 3A Corporation.

Iori, Isao. 2001. Atarashii Nihongo Nyuumon : Kotoba no Shikumi o Kangaeru. Tokyo : 3A Corporation.

Nitta, Yoshio, dkk. 2012. Gendai Nihongo Bunpou 3 (Asupekuto Tensu Kotei). Tokyo : Kuroshio Shuppan.

Pertiwi, Diah Mulya. 2018. Modalitas Tsumori dalam Kalimat Bahasa 
Kiryoku, Volume 3 No 32019

e-ISSN: 2581-0960 p-ISSN: 2599-0497

Tersedia online di http://ejournal.undip.ac.id/index.php/kiryoku

Jepang. Semarang : Universitas Diponegoro.

Sudaryanto. 1993. Metode dan Aneka Teknik Analisis Bahasa. Yogyakarta: Duta Wacana University Press

Sunagawa, Yuriko, dkk. 1999. Nihongo Bunkei Jiten. Tokyo : Kuroshio Shuppan.

Sutedi, Dedi. 2011. Dasar-Dasar Linguistik Bahasa Jepang. Bandung: Humaniora

Tadjuddin, Moh. 2005. Aspektualitas dalam Kajian Linguistik. Bandung : PT Alumni.

Tomomatsu, Etsuko, dkk. 2006. Donna Toki Dou Tsukau Nihongo Hyougen Bunkei 200 Shou Chuu. Tokyo : Aruku.

Verhaar, J.M.W., 2010, Asas-Asas Linguistik Umum. Yogyakarta : Gajah Mada University Press.

https://ejournal.undip.ac.id/index.php/kiryo $\mathrm{ku} /$ article/view/23602 